\title{
California Bearing Ratio Values of Lateritic Soils: Review Paper
}

\author{
${ }^{1 *}$ Yimam Mohammed $\quad{ }^{1}$ Mesfin Girma $\quad{ }^{1}$ Mohammed Demise \\ $1 *$ Civil Engineering Department, wolaita Sodo University, Sodo, Ethiopia \\ 1.Civil Engineering Department, wolaita Sodo University, Sodo, Ethiopia \\ 1.Hydraulic and Water Resource Engineering Department, wolaita Sodo University, Sodo, Ethiopia
}

\begin{abstract}
This paper primarily aiming on reviewing research works conducted on determination of lateritic soil properties basically California Bearing Ratio values. The reviewed documents are conducted in different countries having lateritic soils. These reviewed papers were summarized CBR values for soaked and unsoaked condition. So, this paper presents the value of shear strength of lateritic soils to propose for sub-grade, sub-base, base course and other infrastructure construction material.
\end{abstract}

Keywords: Lateritic soil, California Bearing Ratio, Review Paper

DOI: $10.7176 / \mathrm{CER} / 11-1-01$

\section{INTRODUCTION}

Laterites are soil types rich in iron and aluminum, formed in hot and wet tropical areas. Nearly all laterites are rusty-red because of iron oxides. They form by intensive and prolonged weathering. Tropical weathering leading to laterite is a prolonged process of chemical weathering which produces a variety of resulting soil [37]. The California Bearing Ratio (CBR) test is the most widespread method of determining the bearing strength of the pavement materials and is fundamental to pavement design practice in most countries. The CBR test can be performed both in the laboratory and field. The (CBR) test is usually used to verify the appropriateness of a soil as a sub-grade or sub-base for road and runway design and other construction. This assessment is generally used and applied in design of the base and the sub-base material for roadway.

\section{REVIEWED LITERATURES}

The California bearing ratio (CBR) is an empirical test used to show the shear strength of base and sub base materials used for pavement design. It is also a common test type in evaluation of strength of soils.

[1] Nwadike Henry and Nweke Mathias (2017)

They have done a research on detailed investigation in lateritic soil properties in south eastern Nigeria used as road construction. According to Unified Soil Classification System (USCS) the types of soil found in the study area are SC and SM. The CBR (soaked) value of lateritic soil found in the study area is varies from 33.48 to $62.5 \%$. The unsoaked CBR value varies from 51.29 to $87.5 \%$.

[2] Suksun Horpibulsuk, ApichatSuddeepong, PokinChamket and AvirutChinkulkijniwat C.(2012)

This study mainly worked on compaction behavior of fine grained soils, lateritic soils and crushed rocks. The test results were collected from Bureau of rural road 6, department of rural roads, Thailand. The CBR values are obtained from correlation with maximum dry unit weight.

$$
\mathrm{CBR}_{\max }=2.95^{\gamma} \mathrm{dmax}-9.08
$$

[3] Hussein Elarabi, Mohammed Taha and Tarig Elkhawad (2013)

They have done a research on geotechnical properties of lateritic soils from Muglad basin located in South western of Sudan. The soil type for this soil is SC. According to this study, majority of samples have CBR values of 4 to $52 \%$. But one sample has CBR value of $139 \%$.

[4] Aginam C. H, Nwakaire Chidozie, Nwajuaku A.I (2015)

These Authors have done research on Engineering properties of lateritic soils from Anambra Central Zone, Nigeria. The type of soil classified under USCS classification system is SC. The soaked CBR value of samples collected from borrow pit in Neni, Nimo, Enugwu Ukwu and Obeledu are 28\%, 27\%, 25\% and 22\% respectively. [5] Piti Chantruthai, Thananan Areepong, Sasitorn Issaro and Saravut Jaritngam (2017)

Investigation of lateritic soil properties and impacts from Quarrying activity on communities in southern Thailand, is conducted by these researches. These samples were collected from Ban Khuan Chang, Ban Huayoan and Ban Thung Don. The soil types are clayey sand (SC), sandy clays (CL) and gravel-sand-clay (GC) with CBR value of $110 \%, 45 \%$ and $110 \%$ respectively.

[6] Ademila, Omowumi (2017)

The researcher was conducted an investigation on research on Engineering evaluation of lateritic soils for failed highway sections found in southern Nigeria. The specific location of the study area is Kajola-Oda road. The types of soil found in the study area according to AASHTO classification are A-2-6, A-6 and A-7-6. The unsoaked and soaked CBR values are varing from $14 \%$ to $32 \%$ and $3 \%$ to $11 \%$ for failed section respectively. The unsoaked and soaked CBR values are varing from $36 \%$ to $43 \%$ and $15 \%$ to $23 \%$ for stable section 
respectively.

[7] Oladele A. Omotoso, Olusola J. Ojo \& Emmanuel T. Adetolaju (2012)

The title of this paper is Engineering properties of lateritic soils around Dall Quarry in Sangu area, Ilorin, Nigeria. The soil type under this investigation is CL. The unsoaed and soaked CBR value are $4 \%$ to $5 \%$ and $2 \%$ to $3 \%$ respectively.

[8] Ayodele A.L. and Falade F.A. (2016)

These two researchers have studied some of geotechnical properties of selected sub-base materials for road construction. The soil samples were collected from specific areas of Mokuro road, Ede road1 and Ede road 2. The soil types are $\mathrm{CL}, \mathrm{ML} / \mathrm{OL}$ and $\mathrm{OH} / \mathrm{MH}$ respectively. The CBR values were presented correlated with maximum dry density and optimum moisture content. The correlation in between CBR and MDD with $\mathbb{R}^{2}$ value of 0.8673 .

$$
\begin{array}{r}
\mathrm{CBR}=1.2613^{\mathrm{OMC}^{2}}-48.18 \mathrm{OMC}+463.59 \\
\mathrm{CBR}=39.17 \mathrm{MDD}-65
\end{array}
$$

[9] K.C. Onyelowe and J.C. Agunwamba (2012)

Geotechnical examination of the geophysical properties of Olokoro borrows site lateritic soil for road works. The specific location of the borrow pit Olokoro, north L.G.A.Abia state of Nigeria. The soil type according to AASHTO classification is A-2-7. It has CBR value of $26 \%$.

[10] I. Akiije (2016)

He was conducted this research on stabilization of A-2-7 lateritic soil and strength characteristics using three selected cements. The location of this specific sample area is Ondo town environs borrow pit in Nigeria. The unsoakked and soaked CBR value are $23.5 \%$ and $9.5 \%$ respectively.

[11] TIJANI, Murtadha Adekilekun, AKINLEYE, Monsuru Tunde, JAIYEOBA and Kehinde Folake (2017)

They have worked detailed investigation on Engineering properties of laterites obtained in Ede, Southwestern, Nigeria. The soil type classified under USCS classification is SC. According to AASHTO classification soil samples were classified under A-2-4 and A-2-6, with soaked and unsoaked CBR values varying from $42 \%$ to $74 \%$ and $35 \%$ to $85 \%$ respectively.

[12] Abebaw Zelalem (2005)

The topic of this paper is Basic engineering properties of lateritic soils found in Nejo-Mendi road construction, Welega. According to USCS and AASHTO soil classification system, these soil samples have grouped under silty gravel and A-2-7 respectively. The unsoaked CBR value is varies from $22 \%$ to $79 \%$.

[13] A. B. Alabi, A. O. Olutaiwo, and A. O. Adeboje (2015)

Evaluation of rice hush ash stabilized lateritic soil as sub-base in road construction was conducted by these scholars. The soil samples were collected from borrow pit for rehabilitation of Ibese road at Egbe village, agong Igbogbo-Ikorodu road, Lagos state. The type of soil samples found in study area according to USCS and AASHTO classification are silty clay and A-7 respectively. The soaked and unsoaked CBR value of $10.25 \%$ and $12.3 \%$.

[14] Ashenafi Mulugeta (2016)

The research work done by Ashenafi, is mainly focused on Soaked CBR value determination from laboratory DCP test for Addis Ababa red clay soil. According to AASHTO classification system, these soils are classified under A-7-5 and A-7-6. The samples were collected from Semen Mazegajja, Asco, Gulelle Park and Shiromeda area. The soaked unsoaked CBR values for these locations are 4.98\%-10.8\%, 4.48\%-16.03\%, $12.02 \%-17.53 \%$ and $31.13 \%-33.64 \%$, and unsoaked CBR values are $74.62 \%-90.39 \%, 40.53 \%-78.88 \%, 56.09 \%-85.39 \%$ and $55.34 \%-76.37 \%$ respectively.

[15] Aginam, C. H., Chidolue, C. A., and Nwakaire, C. (2014)

They have done research on Geotechnical properties of lateritic soils from Northern zone of Anambra State, Nigeria. The investigations were done to use these soils for Obosi, Umunya, Awkuzu and Igbariam towns' road construction. According to USCS and AASHTO soil classification system, the soils are classified under SC and A-2-4 respectively. The soaked CBR value ranges from $45 \%$ to $58 \%$. And also California bearing ratio is correlated with maximum dry density and optimum moisture content.

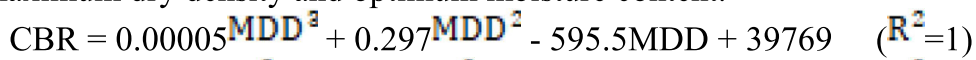

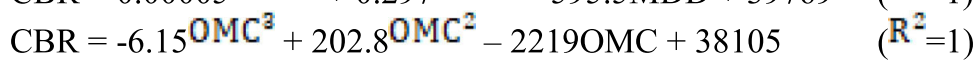

[16] Olugbenga O. Amu and Akinwole A. Adetuberu (2010)

The researches were done on Characteristics of Bamboo leaf ash stabilization on lateritic soil in highway construction. The three soil samples are collected from location of Osun state, Nigeria. According to AASHTO and USCS classification system, the soil types are A-2-4, A-2-5 and A-2-7, and silty/clayey gravel and sand respectively. The unsoaked CBR values are varying from $5.44 \%$ to $11.42 \%$ respectively.

[17] Avwenagha E. Oghenero, Arong T. Okey, Overare Brume, Okunuwadje S. E. and Osokpor Jerry (2014) They have conducted research on classification and compaction characteristics of lateritic soils of Warri, Delta 
state, Nigeria. The soil types according to USCS and AASHTO classification system in different location of study area for PTI road behind first bank, PTI road Agofure park, Urhobo college, Jefia Estate Enerhen, Udu area (SEDCO), Ujevwu, Ejeba(WIBP) and EjebaChevron are CL and A-2-4, CL and A-2-4, SM and A-3, SM andA-3, CL and A-2-4, CL and A-6, CL and A-2-4 and CL and A-2-4 respectively. The soaked CBR value vary from $10.6 \%$ to $26.1 \%$.

[18] Owoyemi O.O and Adeyemi G.O (Ph.D) (2012)

They have done research on Highway geotechnical properties of some lateritic soils from the sedimentary terrain of the Lagos-Ibadan highway. The soil types according to USCS and AASHTO classification are CL and A-7 respectively. The soaked and unsoaked CBR values of this soil are varying from $2.84 \%$ to $2.55 \%$ and $5.29 \%$ to $13.04 \%$ respectively.

[19] G.P. Ojo, U.G. Igbokwe, K.K. Nwozor and C.J. Egbuachor (2016)

This research mainly focused on Geotechnical properties of lateritic over burden material on the charnockite and Gneiss complexes in Ipele - Owo area, Southern Nigeria. Based on Unified Soil Classification System, the soil types found in this research is $\mathrm{CL}$ and $\mathrm{CH}$. The soaked CBR value of soil is varyies from $47 \%$ to $58 \%$.

[20] O.C. Okeke, I. B. Duruojinnaka, H.N. Echetama, C.C. Paschal, C.J. Ezekiel, E.J. Okoroafor and E.O. Akpunonu (2016)

They have conducted the research on Geotechnical and Geochemical characterization of lateritic soil deposits in parts of Owerri, South Eastern Nigeria for road construction. Three soil samples were collected from two borrow pit sites site which are Portharcourt-Owerri Expressway and Ihiagwa sand mines. The soil types collected from these areas and presented on the plasticity chart are CL and CL-ML. The unsoaked CBR values of these samples are $63 \%, 43 \%$ and $39 \%$. The soaked CBR values are $33 \%, 28 \%$ and $11 \%$.

[21] Zubair Saing, Lawalenna Samang, Tri Harianto and Johannes Patanduk (2017)

According to these authors, the research mainly focuses on studying on characteristics of lateritic soil with lime stabilization as a road foundation. The soil types classified according to USCS and AASHTO, it is classified under $\mathrm{CH}$ and A-7-6 respectively. These materials are collected from Sorowako, East Luwu Regency South Sulawesi. The unsoaked CBR value is $22.99 \%$.

[22] Layade Gideon Oluyinka and Ogunkoya Charles Olubunmi (2018)

They have done research on geotechnical properties of lateritic soil as sub-grade and base material for road construction in Abeokuta, SouthWest Nigeria. The specific location of collected sample is Sagamu Abeokuta Express road, Oke Mosan. The specific types of soils are clay and silty clay. The unsoaked CBR value is varying from $12.52 \%$ to $55.84 \%$.

[23] Gopalakrishnan Vaidyanathan, P.V.V Satyanarayana, V. Brahmam and P.S. Naidu (2018)

They have done research on Parameters affecting the efficiency of red gravel soils as road construction material. Twenty eight soil samples were collected from different locations of North Coastal district of Andhra Pradesh. According to IS classification system, the sixteen soil samples are categorized under GC and twelve of them are SC. Sixteen soil samples have Soaked CBR value of $21 \%$ to $38 \%$. And twelve of them have soaked CBR value of $16 \%$ to $24 \%$.

[24] Philémon Zo'o Zame, Philippe Samba Assomo and Josephine Nchekwube Onwualu (2017)

This research work addresses the Assessment of geotechnical properties of lateritic gravels from SouthCameroon road network. One hundred forty four samples are collected from this area. Fifty soil samples are collected from centre region, fifty of them are from East and forty four samples are from South region. The soil types are categorized under A-2-7. According to USCS classification system, these soils are classified under silt to gravel. The soaked CBR value have varied from $30 \%$ to $90 \%$.

[25] F.C. Ugbe (2011)

This author has done research on basic engineering geological properties of lateritic soils from Western Niger Delta. The locations of samples are collected from Edo and Delta States of Nigeria. The specific areas are Benin, Warri and Asaba. One hundred fifty two samples are collected from these areas. The soil types according to AASHTO classification system, are classified under A-2, A-6 and A-7. The soils classified by USCS are clayey sand and sandy clay. The soaked CBR values are varies from $3 \%$ to $43 \%$.

[26] H. Elarabi, M. Taha and T. Elkhawad (2013)

These researchers have conducted research on some of the geotechnical and geological properties of lateritic soils from Muglad basin located in the South Western part of Sudan. The soils found in the study area according to USCS classification system are gravels and clayey sands. The soaked CBR value is varying from 5\% to $139 \%$.From twelve test pit, only one test pit has CBR value of $139 \%$ but most of them are varying from $5 \%$ to $70 \%$.

[27] Osuji O.S and Akinwamide J.T (2018)

The research worked by these scholars is Engineering properties of lateritic soils in Ado-Ekiti, South Western Nigeria. The soils classified under this study area are clay and silty gravely sand and A-2-4, A-26, A-6 and A-75 soils. The soaked and unsoaked CBR values are varying from $4 \%$ to $53 \%$ and $7 \%$ to $95 \%$ respectively. 
[28] Memudu Quadri, Oluwatosin Alao, Oluwaseun Akindipe and Olufikayo Aderinlewo (2017)

The research topic has focused on assessment of beach sand as lateritic soil stabilizer. Soil samples are collected from Niger Delta Development Corporation (NDDC) water tower, behind Federal University of Technology, Akure (FUTA) sport complex, Nigeria. The soil type found in the study area is fair to poor clayey soil. The soaked and unsoaked CBR values are $4.53 \%$ and $3.46 \%$.

[29] Habeeb A. Quadr, Olabambo A. Adeyemi, Oladipupo S. Olafusi (2012)

The research topic conducted by these Authors is investigation of the geotechnical properties of lateritic soils as subgrade and base material for road construction in Nigeria. The specific location of soil samples are Omolayo road in Akobo area of Lagelu local government, Oyo state, Nigeria. The soil types found in the study area according to AASHTO classification are A-1-b and A-2-4. The unsoaked CBR value is varying from $78 \%$ to $132 \%$.

[30] Afeez Adefemi BELLO (2012)

The research was focused on Regression analysis between properties of sub-grade lateritic soil. The specific location of the study area is Osogbo, South Western Nigeria. The soil type according to USCS and AASHTO classification system, are coarse gravel soil and A-2-6 respectively. The soaked and unsoaked CBR values are varying from $26 \%$ to $34 \%$ and $64 \%$ to $85 \%$ respectively.

[31] Oluwapelumi O. Ojuri (2013)

This research was worked on Predictive shear strength models for tropical lateritic soils. Six soil samples were collected from FUTA six locations in Nigeria. The soil types according to AASHTO classification system are A2, A-6 and A-7. The unsoaked CBR value varying from $35 \%$ to $87 \%$.

[32] E. I. Okoyeh, O. E. Ejezie, H. N. Ezeh and H. C. Okeke (2017)

They have done research on Evaluation of Ihiala lateritic soils for use as sub-grade material in road construction. It is found in the southern part of Nigeria. The soil types according to AASHTO and USCS classification system are A-2-4, A-4, A-6 and A-7, and clayey sands (SC). The soaked CBR values are varying from $2 \%$ to $11 \%$.

[33] Charles A. Adams, Ernest Apraku and Richter Opoku-Boahen (2015)

This research was done on Effect of triaxial geogrid reinforcement on CBR Strength of natural gravel soil for road pavements. The specific location of this study is Kumasi in Ghana. The soil type found in the study area is gravel soil. The soaked and unsoaked CBR values are $50.3 \%$ and $71.7 \%$ respectively.

[34] S. A. N. Mohd Yusoff, I. Bakar, D.C. Wijeyesekera, A. Zainorabidin and A. Madun (2015)

These authors have done research of comparison of geotechnical properties of laterite, kaolin and peat soils. The collected samples were located in Bukit Banang, Batu Pahat, Malaysia. According to USCS and AASHTO classification system, the soil type found in this study area is CL and A-7-6 respectively. The soaked and unsoaked $\mathrm{CBR}$ values are $46.82 \%$ and $51.5 \%$ respectively.

[35] Amadi A.N., Akande W. G., Okunlola I. A., Jimoh M.O. and Francis Deborah G. (2017)

Basically these researchers were conducted the assessment of the geotechnical properties of lateritic soils in Minna, North Central Nigeria for road design and construction. Specifically, the soil samples were located in Sauka-Kahuta Industrial layout, behind the Minna building material market. The soil types according to USCS classification system are SM, SC and SC-SM. The soaked and unsoaked CBR values are varing from 5.1\% to $72.7 \%$ and $0 \%$ to $83.8 \%$ respectively.

[36] Emeka Segun Nnochiri and Olufikayo .O. Aderinlewo (2016)

They have accomplished a research on geotechnical properties of lateritic soil stabilized with banana leaves ash. These soil samples were collected from the specific location of Akure, Southwestern part of Nigeria. According to USCS and AASHTO classification system, the soil types are SC and A-7-5 respectively. The unsoaked CBR value is $10.42 \%$.

\section{CONCLUSION}

Most reviewed paper under their investigation was categorized under coarse grained soils. According to USCS and AASHTO classification system, the reviewed papers have been classified under SC, SM, GC, CL, MH/OH $\mathrm{CH}, \mathrm{ML}$ and A-1-b, A-2, A-3, A-4, A-6 and A-7 respectively. Assessment or compilation of the CBR values of lateritic soils whether it is suitable for the respected construction activities or not. Some of the CBR values worked in different study areas are presented in this paper.

\section{REFERENCES}

[1]. Nwadike Henry Onyebuchi, Nweke Obisi Mathias (2016), Detailed Investigation of Index Properties and Rate of Consolidations of Nguzu Edda Lateritic Soils (South-Eastern Nigeria) Used for Road Construction, Nigeria.

[2]. Suksun Horpibulsuka,n, ApichatSuddeepongb, PokinChamketa,c, AvirutChinkulkijniwat (2012), Compaction behavior of fine-grained soils, lateritic soils and crushed rocks, Thailand.

[3]. Hussein Elarabi, Mohammed Taha and Tarig Elkhawad (2013), Geotechnical properties of lateritic soils 
from muglad basin located in the south - western part of sudan.

[4]. Aginam C. H, Nwakaire Chidozie, Nwajuaku A.I (2015), Engineering Properties of Lateritic Soils from Anambra Central Zone, Nigeria

[5]. Piti Chantruthai, Thananan Areepong, Sasitorn Issaro, and Saravut Jaritngam (2017), Investigating Lateritic Soil Properties and Impacts from Quarrying Activity on Communities in Southern Thailand: A Case Study, Thailand.

[6]. Ademila, Omowumi (2017), Engineering Evaluation of Lateritic Soils of Failed Highway Sections in Southwestern Nigeria.

[7]. Oladele A. Omotoso, Olusola J. Ojo \& Emmanuel T. Adetolaju (2012), Engineering Properties of Lateritic Soils around Dall Quarry in Sango Area, Ilorin, Nigeria.

[8]. Ayodele A.L. and Falade F.A. (2016), Some Geotechnical Properties of Selected Sub-Base Materials for Road Construction, Nigeria.

[9]. K.C. Onyelowe and J.C. Agunwamba (2012), Geotechnical examination of the geophysical properties of olokoro borrow site lateritic soil for road works, Nigeria.

[10].I. Akiije (2016), Stabilization of A-2-7(0) Laterite Soil and Strength Characteristics Using Three Selected Cements Individually, Nigeria.

[11].TIJANI, Murtadha Adekilekun, AKINLEYE, Monsuru Tunde, JAIYEOBA and Kehinde Folake (2017), Engineering Properties of Laterites Obtained in Ede, Southwestern Nigeria

[12]. Abebaw Zelalem (2005), Basic Engineering Properties of Lateritic Soils Found in Nejo - Mendi Road Construction Area, Welega, Ethiopia.

[13].A. B. Alabi, A. O. Olutaiwo, and A. O. Adeboje (2015), Evaluation of Rice Husk Ash Stabilized Lateritic Soil as Sub-base in Road Construction, Nigeria.

[14]. Ashenafi Mulugeta (2016), Soaked CBR value determination from laboratory DCP test for Addis Ababa red clay soil, Ethiopia.

[15].F.C. Ugbe (2011), Geotechnical Properties of Lateritic Soils from Northern Zone of Anambra State, Nigeria.

[16]. Olugbenga O. Amu and Akinwole A. Adetuberu (2010), Characteristics of Bamboo Leaf Ash Stabilization on Lateritic Soil in Highway Construction, Nigeria.

[17]. Avwenagha E. Oghenero, Arong T. Okey, Overare Brume, Okunuwadje S. E. and Osokpor Jerry (2014), Classification and compaction characteristics of lateritic soils of Warri, Delta state, Nigeria.

[18]. Owoyemi O.O and Adeyemi G.O (Ph.D) (2012), Highway Geotechnical Properties of Some Lateritic Soils from the Sedimentary Terrain of the Lagos - Ibadan Highway, Nigeria.

[19].G.P. Ojo, U.G. Igbokwe, K.K. Nwozor and C.J. Egbuachor (2016), Geotechnical Properties of Lateritic Overburden Materials on the Charnockite and Gneiss Complexes in Ipele-Owo Area, Southwestern Nigeria.

[20].O.C. Okeke, I. B. Duruojinnaka, H.N. Echetama, C.C. Paschal, C.J. Ezekiel, E.J. Okoroafor and E.O. Akpunonu (2016), Geotechnical and geochemical characterization of lateritic soil deposits in parts of owerri, southeastern nigeria, for road construction, Nigeria.

[21].Zubair Saing, Lawalenna Samang, Tri Harianto and Johannes Patanduk (2017), Study on Characteristic of Laterite Soil with Lime Stabilizationas a Road, Foundation, Indonesia.

[22].Layade Gideon Oluyinka and Ogunkoya Charles Olubunmi (2018), Geotechnical properties of lateritic soil as sub-grade and base material for road construction in Abeokuta, SouthWest Nigeria.

[23]. Gopalakrishnan Vaidyanathan, P.V.V Satyanarayana , V. Brahmam and P.S. Naidu (2018), Parameters Affecting the Efficiency of Red Gravel Soils as Road Construction Material, Andhra, India.

[24]. Philémon Zo'o Zame, Philippe Samba Assomo and Josephine Nchekwube Onwualu (2017), Assessment of Geotechnical Properties of Lateritic Gravels from South-Cameroon Road Network, Nigeria.

[25].F.C. Ugbe (2011), Basic Engineering Geological Properties of Lateritic Soils from Western Niger Delta, Abraka.

[26].H. Elarabi, M. Taha and T. Elkhawad (2013), Some Geological and Geotechnical Properties of Lateritic Soils from Muglad Basin Located in the South-Western Part of Sudan.

[27]. Osuji O.S and Akinwamide J.T (2018), Engineering Properties of Lateritic Soils in Ado-Ekiti, South Western Nigeria.

[28]. Memudu Quadri, Oluwatosin Alao, Oluwaseun Akindipe and Olufikayo Aderinlewo (2017), Assessment of Beach Sand as Lateritic Soil Stabilizer, Nigeria.

[29].Habeeb A. Quadr, Olabambo A. Adeyemi, Oladipupo S. Olafusi (2012), Investigation of the Geotechnical Engineering Properties of Laterite as a Subgrade and Base Material for Road Constructions in Nigeria.

[30]. Afeez Adefemi Bello (2012), Regression Analysis between Properties of Sub-grade Lateritic Soil, Osogbo.

[31]. Oluwapelumi O. Ojuri (2013), Predictive Shear Strength Models for Tropical Lateritic Soils, Nigeria.

[32].E. I. Okoyeh, O. E. Ejezie, H. N. Ezeh and H. C. Okeke (2017), Evaluation of Ihiala Laterites for Use as Sub-grade Material in Road Construction, Nigeria.

[33]. Charles A. Adams, Ernest Apraku and Richter Opoku-Boahen (2015), Effect of Triaxial Geogrid 
Reinforcement on CBR Strength of Natural Gravel Soil for Road Pavements, Ghana.

[34].S. A. N. Mohd Yusoff, I. Bakar, D.C. Wijeyesekera, A. Zainorabidin and A. Madun (2015), Comparison of geotechnical properties of laterite, kaolin and peat, Malaysia.

[35]. Amadi A.N., Akande W. G., Okunlola I. A., Jimoh M.O. and Francis Deborah G. (2017), Assessment of the Geotechnical Properties of Lateritic Soils in Minna, North Central Nigeria for Road design and Construction, Nigeria.

[36]. Emeka Segun Nnochiri and Olufikayo .O. Aderinlewo (2016), Geotechnical Properties of Lateritic Soil Stabilized with Banana Leaves Ash, Nigeria.

[37]. Davis A. D., Bacon, W. G.; Osborne R. C. (2004). "The past and the future of Nickel laterites; PDAC International Convention. 